\title{
Counseling Quality of Dangerous Signs of Pregnancy Health in Work Region of Urban and Rural Puskesmas (Public Health Center) Jeneponto
}

\author{
Hafidah Amiruddin ${ }^{1 *}$, Ansariadi Ansariadi ${ }^{1}$, Sukri Palutturi ${ }^{2}$, M. Wahidin ${ }^{1,3}$, Abdul Rahman Akmal $^{4,5}$, Zhanaz Tasya ${ }^{1,6}$, Iva Hardi Yanti ${ }^{1}$ \\ ${ }^{1}$ Department of Epidemiology, Faculty of Public Health, Hasanuddin University, Makassar, Indonesia; ${ }^{2}$ Department of Health \\ Administration and Policy, Faculty of Public Health, Hasanuddin University, Makassar, Indonesia; ${ }^{3}$ Majene Health Office, Majene \\ Regency, West Sulawesi, Indonesia; ${ }^{4}$ Department of Health Promotion and Behavioral Sciences, Faculty of Public Health, \\ Hasanuddin University, Makassar, Indonesia; 5 Jeneponto Health Office, Jeneponto Regency, South Sulawesi, Indonesia; \\ ${ }^{6}$ Department of Epidemiology, Faculty of Public Health, Muhammadiyah University, Palu, Indonesia
}

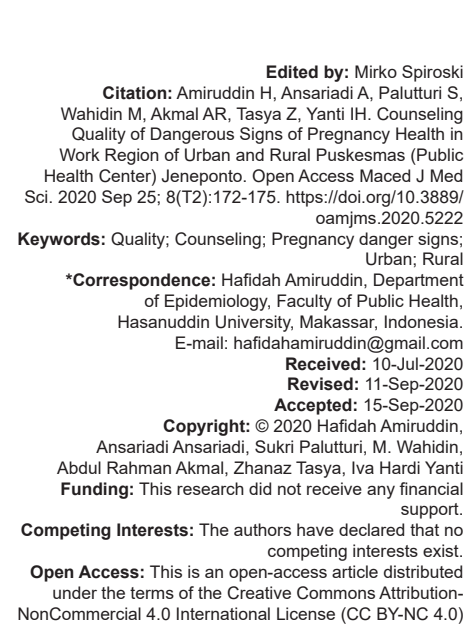

Abstract

BACKGROUND: Quality healthcare is the standard of care received by citizens who are entitled to guarantee their health status due to the poor quality of health care that affect the high mortality.

AIM: This study aimed to determine the difference in counseling quality of pregnancy dangerous signs at the public health centers of urban and rural areas in Jeneponto regency.

METHODS: The type of study was analytical observation with a cross-sectional study design. The populations of this research are all pregnant women in Jeneponto regency in October 2015-May 2016 at the work area of Urban and Rural Public Health centers. There were 278 respondents obtained by proportionate stratified random sampling. Data analysis used computer application of SPSS examined with the Chi-square test.

RESULTS: The results indicate that $85.3 \%$ of counseling quality of pregnancy dangerous signs in the work area of urban and rural Puskesmas are categorized bad. There is a difference of counseling quality of pregnancy dangerous sign component of vagina bleeding $(p=0.000)$, severe headache $(p=0.000)$, visual problems/blurred sight $(p=0.000)$, swelling on face and hand $(p=0.001)$, and severe abdominal pain $(p=0.000)$, fetus movement is lacking or not felt $(p=0.000)$ and fever $(p=0.000)$

CONCLUSION: There is no difference in counseling quality based on age, education, job, and parities.

\section{Introduction}

Maternal and child health is a matter of public health. This is referred to in the global concessions of the millennium development goals (MDGs) and also continued in Sustainable Development Goals (SDGs) [1]. The maternal mortality rate in Indonesia is quite high, based on 2012 IDHS data, the maternal mortality rate is $359 / 100,000$ live births [2].

Data on visits to care can be a reference for assessing the good quality of services provided by health workers, although there is no agreement on ANC quality assessment indicators [3]. Research in Nigeria shows that only $4.6 \%$ of women receive good quality ANC services, while almost $1.0 \%$ do not receive one complete component of ANC examination [4]. The patient satisfaction during ANC examination is very important because it influences patients to be more inclined to comply with routine examinations in using primary health services. Research in Bahir showed that $98.9 \%$ of respondents were intrapersonally satisfied when examining and consulting [5].

The problem of ANC services in Indonesia is almost the same as in other developing countries. Such an incident in Sub-SaharanAfrica shows that even though the ANC service coverage is high, it is still followed by a high maternal mortality rate. Hence, this makes Graham assess the gap between the amount of ANC coverage and maternal mortality [6]. Pregnancy complications are one of the causes of the high maternal mortality rate in Indonesia [7]. This complication can occur because the mother does not recognize the danger signs of pregnancy that can cause complications.

The quality of antenatal care services is determined by seven components. One of them is antenatal care counseling. Researching the quality of counseling on pregnancy danger signs is very important to do because this is very closely related to the health of pregnant women. With counseling, pregnant women get a solution to the pregnancy problems that are being 
experienced. In this case, the things must be done and which should be avoided during pregnancy so that the counseling component can improve the degree of health of pregnant women.

Based on service coverage data, it shows that the ideal $\mathrm{K} 1$ and $\mathrm{K} 4$ indicators nationally are $81.6 \%$ (Ministry of Health, 2013). However, this data does not indicate the quality of services provided to pregnant women. The regencies/cities with the highest maternal mortality rates include West Sulawesi, NTB, and NTT, which are $90 / 100,000 \mathrm{KH}$. This is what puts Indonesia has a maternal mortality rate of $288 / 100,000 \mathrm{kh}$ from 33 provinces. Moreover, it still has not reached the target of reducing the global maternal mortality rate to $<70 / 100,000$ live births [1]

The implementation of the ANC in South Sulawesi $\mathrm{K} 1$ and ANC coverage was at least four visits each of $75.9 \%$ and $95.7 \%$ [8]. However, this high coverage does not guarantee a decrease in maternal mortality in South Sulawesi Province. Jeneponto is one of the areas with health problems which have the highest maternal mortality rate for three years in a row, namely, from 2013 to 2015, with figures of 170, 235, and $170 / 100,000 \mathrm{KH}$, respectively [9].

According to the IDHS data on pregnant women who received counseling about pregnancy, danger signs in urban areas amounted to $57.1 \%$ and in rural areas amounted to $48.7 \%$. Findings from studies conducted in Norway show that there are many implications that arise, and it is known that the interests of pregnant women from rural areas are low. Therefore, there is a need that counselors must be posted to rural areas of the community to enable them to advise them on the importance of antenatal visits, more counseling must be provided for pregnant women, especially in rural areas to motivate their antenatal interests. Counselors should be more involved in counseling sessions for pregnant women in different hospitals and health centers [10].

Data on the number of pregnant women receiving data counseling services in Jeneponto Regency were unavailable. Moreover, the high maternal mortality rate is caused by complications. Moreover, there is no research on counseling quality in Jeneponto Regency. This is what underlies researchers to conduct research on the quality of counseling services in pregnancy danger signs in the Rural Areas Health Center and Urban Areas Health Centers in Jeneponto Regency 2016. This study aims to compare the quality of counseling for pregnancy danger signs in the Urban Health Centers and the Rural Health Centers in the Regency, Jeneponto.

\section{Materials and Methods}

This research was carried out in the Urban Area and Community Health Center in Rural Areas,
Jeneponto Regency, South Sulawesi Province. This type of research is observational analytic with a "crosssectional study" design. The population in this study were all pregnant women in Jeneponto Regency in October 2015-May 2016, amounting to 4156 pregnant women. The data were obtained from the Profile of the Jeneponto District Health Service in 2015. The sample in this study was pregnant women who had visited to utilize counseling services for pregnancy danger signs at the Jeneponto Health Center and met the inclusion criteria, with a total sample of 287 respondents. The inclusion criteria are pregnant women who live in Jeneponto and have visited Puskesmas during the study period.

Data collection is done through direct interview techniques using a questionnaire, and direct observation using a checklist. Secondary data were obtained from the District Health Office of Jeneponto. Data analysis was performed with the SPSS program and statistical tests using univariate tests with frequency and bivariate analysis of the Chi-square test.

\section{Results}

The results showed that the distribution of respondents based on characteristics in urban and rural health centers in Jeneponto Regency, by age group, showed that the most respondents were the 17-25 year age group that was 129 people (46.4\%), and the lowest was the age group of 12-16 years which was three people (1.1\%). Regarding the education of most respondents, there were 95 graduates $(34.2 \%)$ graduating from junior high school, and the lowest did not graduate from elementary school and graduated from college, respectively, with 17 people $(6.1 \%)$. Moreover, based on employment it was shown that most respondents were IRT jobs, namely, as many as 263 people $(94.6 \%)$, and the lowest was in the work of 1 private employee $(0.4 \%)$ (Table 1$)$.

Table 1: Distribution of respondents based on characteristics in the Puskesmas and midwife practices of Jeneponto regency

\begin{tabular}{lll}
\hline Characteristics & Frequency & $\%$ \\
\hline Age (Year) & 3 & \\
$12-16$ & 129 & 1.1 \\
$17-25$ & 121 & 46.4 \\
$26-35$ & 25 & 43.5 \\
$36-45$ & & 9.0 \\
Education & 17 & 6.1 \\
$\quad$ Not completed in primary school & 90 & 32.4 \\
Graduated from elementary school & 95 & 34.2 \\
Graduated from middle school & 59 & 21.2 \\
Graduated from high school & 17 & 6.1 \\
Graduated from college & 17 & 6.1 \\
Not completed in primary school & & \\
Occupation & 263 & 94.6 \\
IRT & 9 & 3.2 \\
Entrepreneur & 5 & 1.8 \\
Civil servants & 1 & 0.4 \\
Private employees & & \\
\hline
\end{tabular}

The counseling status of respondents showed that most respondents did not get counseling as many as 
143 people (51.4\%), while those getting counseling were 135 people (48.6\%) (Table 2$)$. The results of counseling quality research related to respondents' knowledge in urban and rural health centers showed that the highest quality of counseling related to poor quality as many as 237 people (85.3\%), while those getting good quality counseling were 41 people (14.7\%) (Table 3).

The results of the bivariate analysis between the quality of counseling knowledge with the counseling component showed that respondents who did not receive counseling related to vaginal bleeding and had poorer quality were 159 patients (91.9\%).

Table 2: Frequency distribution of respondents based on counseling status at the Puskesmas and midwife practices in Jeneponto regency

\begin{tabular}{lll}
\hline Counseling & Frequency & $\%$ \\
\hline Yes & 135 & 48.6 \\
No & 143 & 51.4 \\
\hline
\end{tabular}

Statistical test results indicate that there is a difference in the quality of counseling on pregnancy danger signs related to vaginal bleeding counseling in rural and urban health centers $(p=0,000)$ (Table 4).

Table 3: Frequency distribution of respondents based on ANC service quality at the Puskesmas and midwives in the practice of Jeneponto regency

\begin{tabular}{lll}
\hline Kualitas Pelayanan ANC & Frekuensi & $\%$ \\
\hline Kualitas Baik & 41 & 14.7 \\
Kualitas Buruk & 237 & 85.3 \\
Total & 278 & 100.0 \\
\hline
\end{tabular}

The counseling component related to pain/ headache which is severe and has more poor quality is 197 patients $(93.4 \%)$. Statistical test results show that there are differences in the quality of counseling on pregnancy danger signs associated with severe pain/headache counseling in rural and urban health centers $(p=0,000)$. Respondents who did not receive counseling related to visual problems/blurred vision and had more poor quality were 195 patients (93.3\%). Statistical test results show that there is a difference in the quality of counseling on pregnancy danger signs related to counseling on visual/blurred vision problems in rural and urban health centers $(p=0.000)$ (Table 4).

Table 4: ANC quality analysis based on ANC components in the Jeneponto district health center and midwife practice

\begin{tabular}{|c|c|c|c|c|c|c|c|}
\hline \multirow[t]{3}{*}{ Variable } & \multicolumn{4}{|c|}{ Quality } & \multicolumn{2}{|c|}{ Total } & \multirow[t]{3}{*}{$p$} \\
\hline & \multicolumn{2}{|c|}{ Good } & \multicolumn{2}{|l|}{ Poor } & \multirow[t]{2}{*}{$\mathrm{n}$} & \multirow[t]{2}{*}{$\%$} & \\
\hline & $\mathrm{n}$ & $\%$ & $\mathrm{n}$ & $\%$ & & & \\
\hline \multicolumn{8}{|c|}{ Vaginal bleeding } \\
\hline Yes & 27 & 25.7 & 78 & 74.3 & 173 & 100 & \multirow[t]{2}{*}{0.000} \\
\hline No & 14 & 8.1 & 159 & 91.9 & 105 & 100 & \\
\hline \multicolumn{8}{|c|}{ Severe headaches } \\
\hline Yes & 27 & 40.3 & 40 & 59.7 & 67 & 100 & \multirow[t]{2}{*}{0.000} \\
\hline No & 14 & 6.6 & 197 & 93.4 & 211 & 100 & \\
\hline \multicolumn{8}{|c|}{ Visual problems/blurred vision } \\
\hline Yes & 27 & 39.1 & 42 & 60.9 & 69 & Ya & \multirow[t]{2}{*}{0.000} \\
\hline No & 14 & 6.7 & 195 & 93.3 & 209 & Tidak & \\
\hline \multicolumn{8}{|c|}{ Swelling on face and hands } \\
\hline Yes & 25 & 23.4 & 82 & 76.6 & 107 & 100 & \multirow[t]{2}{*}{0.001} \\
\hline No & 16 & 9.4 & 155 & 90.6 & 171 & 100 & \\
\hline \multicolumn{8}{|c|}{ Abdominal pain is severe } \\
\hline Yes & 25 & 26.0 & 71 & 74.0 & 96 & 100 & \multirow[t]{2}{*}{0.000} \\
\hline No & 16 & 8.8 & 166 & 91.2 & 182 & 100 & \\
\hline \multicolumn{8}{|c|}{ Fetal movement is lacking or not felt } \\
\hline Yes & 25 & 36.8 & 43 & 63.2 & 68 & 100 & \multirow[t]{2}{*}{0.000} \\
\hline No & 16 & 7.6 & 194 & 92.4 & 210 & 100 & \\
\hline \multicolumn{8}{|c|}{ Severe headache } \\
\hline Yes & 26 & 41.9 & 36 & 58.1 & 62 & 100 & \multirow[t]{2}{*}{0.000} \\
\hline No & 15 & 6.9 & 201 & 93.1 & 216 & 100 & \\
\hline
\end{tabular}

The counseling component related to swelling on the face and hands that have poor quality is more than 155 patients $(90.6 \%)$. Statistical test results show that there is a difference in the quality of counseling on pregnancy danger signs associated with swelling in the face and hands counseling in rural and urban health centers $(p=0.001)$. Respondents who did not receive counseling related to severe abdominal pain and had more poor quality were 166 patients (91.2\%). Statistical test results show that there is a difference in the quality of counseling on pregnancy danger signs associated with counseling. Abdominal pain is severe in rural and urban health centers $(p=0.000)$ (Table 4).

Respondents who did not receive counseling related to fetal movements were less or not felt and had more poor quality, that is, 194 patients (92.4\%). Statistical test results show that there are differences in the quality of counseling on pregnancy danger signs related to counseling. Fetal movement is less or not felt in rural and urban health centers $(p=0.000)$. Respondents who did not receive counseling related to severe headaches and had more poor quality were 201 patients (93.1\%). Statistical test results show that there is a difference in the quality of counseling on pregnancy danger signs associated with counseling severe headaches in rural and urban health centers $(p=0.000)$ (Table 4).

\section{Discussion}

The results of this study indicate that most respondents are the age group of 17-25 years, which are 129 people $(46.4 \%)$, and the least is the age group of $12-16$ years as many as 3 people $(1.1 \%)$. Regarding education, the highest number of respondents was at junior high school level of 95 people (34.2\%), and the lowest was not graduated from elementary school and graduated from college, respectively, as many as 17 people (6.1\%).

Based on the results of this study, most respondents indicated that most respondents were IRT jobs, namely, 263 people (94.6\%), and the lowest was the employment of 1 private employee $(0.4 \%)$. Regarding counseling status, the majority of respondents did not receive counseling, namely, 143 people (51.4\%) and 135 people (48.6\%). Moreover, research shows that respondents who are not counseling and have more poor quality are 130 patients $(90.9 \%)$.

Health workers, in this case midwives, should provide a complete component of the danger signs of pregnancy when pregnant women make the first contact of pregnancy. This is because, if information about danger signs of pregnancy is not given early in pregnancy, fatal things for the mother and fetus can occur. In this case, it is possible at the time of dizziness for pregnant women to only consider it a natural 
thing and ignore the headache until it continues to a dangerous stage.

This study stated that all components of pregnancy danger signs showed a significant relationship with the quality of maternal knowledge related to counseling ( $p<0.05)$. The respondents who received counseling related to vaginal bleeding (continuous blood spots during pregnancy) were as many as 105 people $(37.8 \%)$, received counseling related to severe pain/headache (persistent and persistent headaches despite resting) were 67 people (24.1\%), counseling related to visual problems/blurred vision (have a rest but the eyes remain blurred) were as many as 69 people (24.8\%), get counseling related to swelling on the face and hands (symptoms experienced at 7-9 months gestational age and blood pressure above normal) were as many as 107 people (38.5\%).

Counseling related to severe abdominal pain (severe abdominal pain and not stopping after rest) as many as 96 people (34.5\%), get counseling related to fetal movements less or not felt (fetuses move at least 3 times in 3 hours, and fetal movements are felt at gestational age 16-20 weeks) as many as 68 people $(24.5 \%)$ and get counseling related to severe headaches (headaches from preeclampsia symptoms and headaches still felt after resting) as many as 62 people $(22.3 \%)$.

The most remembered danger sign among respondents in both study groups was vaginal bleeding, and this is in line with findings from rural Zambia. Vaginal bleeding is also the most advising danger sign in a study that focused on counseling and awareness of women of pregnancy danger signs at selected rural health facilities in Africa.

Research conducted by Hailu [11] in Ethiopia shows that pregnant women who get the danger signs of pregnancy bleeding vaginal bleeding (45.9\%), severe headaches/pain (7.4\%), facial swelling and hands $(3.2 \%)$, severe abdominal pain $(7.0 \%)$, and fetal movements are less or not felt (4.7) and high fever $(9.2 \%)$.

This research shows that pregnant women who know about the components of danger signs of pregnancy are very minimal. Among the seven components of standardized danger signs of pregnancy, only a few pregnant women receive these components. This is due to many factors, one of which is the tendency of health workers (midwives) to not give full counseling about the danger signs of pregnancy. Midwives only explain pregnancy danger signs as complained by pregnant women even though counseling is a complete danger sign of pregnancy to pregnant women at the first visit (K1).

The limited-time of service and the lack of health workers is one of the reasons health workers do not explain in full the components of pregnancy danger signs to pregnant women at the first visit (K1). Encouraging reading the KIA book is an option for midwives.

\section{Recommendation}

Based on this study, all components of pregnancy danger signs are significant with the quality of knowledge related to counseling. Therefore, health workers, in this case midwives, should do more innovative and comprehensive counseling for pregnant women so that fatal things for mothers and fetuses can be avoided.

\section{References}

1. World Health Organization. Trends in Maternal Mortality:1990 to 2015. Geneva: World Health Organization; 2014

2. Kemenkes. Informasi Data dan Informasi Kementerian Kesehatan RI. Jakarta: Ministry of Health; 2014

3. Tetui M, Ekirapa EK, Bua J, Mutebi A, Tweheyo R, Waiswa P, et al. Quality of antenatal care services in Eastern Uganda: Implications for interventions. Pan Afr Med J. 2012;13:1-27. PMid:23308332

4. Fagbamigbe A, Idemudia E. Assessment of quality of antenatal care services in Nigeria: Evidence from a population-based survey. Reprod Health. 2015;12:88. https://doi.org/10.1186/ s12978-015-0081-0

PMid:26382228

5. Ejigu T, Woldie M, Kifle Y. Quality of antenatal care services at public health facilities of Bahir-Dar special zone, Northwest Ethiopia. BMC Health Serv Res. 2013;13(1):1-16. https://doi. org/10.1186/1472-6963-13-443

6. Graham W, Varghese B. Quality: Gaps in the continuum of care. Lancet. 2011;379(9811):5-6.

PMid:21474173

7. Mbalinda S, Nakimuli A, Kakaire O, Osinde MO, Kakande N, Kaye DK. Does knowledge of danger signs of pregnancy predict birth preparedness? A critique of the evidence from women admitted with pregnancy complications. Health Res Policy Syst. 2014;12:60. https://doi.org/10.1186/1478-4505-12-60 PMid:25300499

8. Riskesdas RI. Riset Kesehatan Dasar. Badan Penelitian dan Pengembangan Kesehatan Departemen Kesehatan Republik Indonesia. Jakarta: Republik Indonesia; 2013. https://doi. org/10.6066/jtip.2013.24.2.121

9. Dinkes Jeneponto. Profil Dinas Kesehatan. Jeneponto: Dinkes Jeneponto; 2014.

10. Anyamene A, Nnokolo C, Anyamene N. Antenatal interest of pregnant women in Awka district, Nigeria: Implication for conselling. Eur Sci J. 2014;10(17):412-7.

11. Hailu M, Gebremariam A, Alemseged F. Knowledge about obstetric danger signs among pregnant women in Aleta Wondo district, Sidama Zone, Southern Ethiopia. 2010;20:25-32. https://doi.org/10.4314/ejhs.v20i1.69428 